\title{
Testicular Cancer pT3 TNM Finding v8
}

National Cancer Institute

\section{Source}

National Cancer Institute. Testicular Cancer pT3 TNM Finding v8. NCI Thesaurus. Code C140217.

Testicular cancer in which the tumor invades spermatic cord with or without lymphovascular invasion. (from AJCC 8th Ed.) 